\title{
18. AGE AND PROVENANCE OF CLASTIC HORIZONS FROM HOLE 516F1
}

\author{
W. B. Bryan, Department of Geology and Geophysics, Woods Hole Oceanographic Institution, \\ Woods Hole, Massachusetts \\ and \\ R. A. Duncan, School of Oceanography, Oregon State University, Corvallis, Oregon
}

\begin{abstract}
Qualitative petrographic study of selected clastic horizons within the Eocene section of Hole $516 \mathrm{~F}$ has revealed the presence of abundant fine-grained lithic fragments, probably volcanic, along with coarser fragments of quartz and feldspar apparently derived from a nearby plutonic terrain. In detail, poor sorting, presence of graded bedding, and an abundance of clay suggest these are turbidite horizons locally derived from a mixed volcanic/plutonic terrain, possibly with some direct contribution from contemporary volcanic ash falls. A progressive increase in plutonic versus volcanic components with time is, however, more consistent with an erosional origin for most of this material. Unusual euhedral dark biotite is abundant in several of the lower clastic horizons; it is most easily interpreted as microphenocrysts weathered in situ out of alkalic volcanic ash. Biotite separated from Sample 516F-76-4, 107-115 cm, has been dated by the $\mathrm{K}$-Ar method at about $46 \mathrm{Ma}$. Alkaline volcanoes active on the Rio Grande Rise in the middle Eocene would be the most probable source of this ash and would be consistent with other evidence for potassic, alkaline volcanism along the Rio Grande Rise and at the Tristan da Cunha hot spot.
\end{abstract}

\section{INTRODUCTION}

Shipboard descriptions of smear slides from dark gray sandy intervals in Hole $516 \mathrm{~F}$ suggested that many of these might represent volcanic ash; some horizons were reported to contain volcanic glass. An initial major objective of this study was the isolation of volcanic glass samples for electron microprobe analysis to aid in characterizing the nature of volcanic activity during the middle Eocene. Although more detailed studies have confirmed a substantial volcanic or plutonic igneous contribution to the Eocene section, no fresh glass suitable for analysis was found in these samples. However, radiometric ages (K-Ar) determined for fresh euhedral brown biotite concentrated from one coarse micaceous sand interval relate the biotite to a middle Eocene ( $46 \mathrm{Ma}$ ) volcanic episode, contemporaneous with the sedimentation. This biotite is consistent with the alkalic, and specifically potassic, nature of some volcanic rocks dredged from the Rio Grande Rise. This paper summarizes the major lithologic features of the core intervals studied, the possible nature of the source of this material, and its paleogeographic implications.

\section{LABORATORY METHODS}

All of the intervals studied are predominantly silt and clay. Each sample was soaked in distilled water and repeatedly decanted to remove salt and disperse the clay component. Disaggregation was aided by gentle tamping and stirring; the original grain size and morphology was carefully preserved. Minor carbonate was dissolved in dilute $\mathrm{HCl}$; most of this appears to be organic, but fossils are not abundant in most of the material examined. The clay and silt were decanted, and no attempt has been made to study this material. The remaining clastic residue was dried and examined in immersion oils, water suspension, or epoxy mounts as necessary to best preserve and display the sample.

\footnotetext{
${ }^{1}$ Barker, P. F., Carlson, R. L., Johnson, D. A., et al., Init. Repts. DSDP, 72: Washington (U.S. Govt. Printing Office).
}

By use of magnetic separation and heavy liquids, biotite was concentrated from approximately $35 \mathrm{~g}$ of coarse sand from Sample $516 \mathrm{~F}$ $76-4,107-115 \mathrm{~cm}$. The sample was split into two aliquants, one for potassium and the other for argon analyses. Potassium was determined by atomic absorption spectrophotometry, and argon isotopic compositions were measured using an AEI MS-10S spectrometer equipped with an ${ }^{38} \mathrm{Ar}$ spike pipette system.

\section{DESCRIPTIONS OF INTERVALS AND CLASTIC RESIDUES}

Descriptions of the intervals studied are given in the Appendix. There is a general similarity in the clastic residues from each horizon. They consist of quartz, feldspar, and fine-grained igneous rock fragments that vary mainly in size, proportions, and degree of rounding. A few samples are conspicuously micaceous, with biotite the dominant mica. In Sample 516F-61-1, $44 \mathrm{~cm}$, the clastics are highly rounded, quartz is abundant, and the sediment in general has the appearance of a relatively "mature"' lithic sand. In Sample 516F-72-1, $84 \mathrm{~cm}$, the quartz is less abundant, and the fragments are much more angular. In Sample 516F-76-4, 90-140 cm, lithic fragments dominate and are accompanied by abundant flakes of euhedral brown biotite. These samples, illustrated in Plate 1, Figures 1-4, are typical of the sandy clastic fractions isolated from these core intervals. In many cases, the coarser clastics appear to be thoroughly mixed with the silt and clay, suggesting either poor initial sorting of the sediment, or bioturbation of the intervals studied. No fresh volcanic glass was encountered.

Table 1 reports duplicate age determinations for biotite separated from Sample 516F-76-4, 107-115 cm. The samples generated high proportions of radiogenic argon, and the measured ages agree within experimental error at $46.3 \pm 0.7 \mathrm{Ma}$, or middle Eocene. Significant argon loss is unlikely in view of the reproducibility of the age determinations and their compatibility with the biostrati- 
Table 1. K-Ar age determinations on biotite from coarse sand within Sample 516F-76-4, 107-115.

\begin{tabular}{|c|c|c|}
\hline Measurement & Determination \#1 & Determination \#2 \\
\hline$\% \mathrm{~K}$ & 6.836 & 6.836 \\
\hline $\begin{array}{l}{ }^{40} \mathrm{Ar} \text { radiogenic } \\
\times 10^{-5} \mathrm{~cm}^{3} / \mathrm{g}\end{array}$ & 1.2325 & 1.2600 \\
\hline $\begin{array}{l}\% 40 \mathrm{Ar} \\
\text { radiogenic }\end{array}$ & 96.4 & 94.2 \\
\hline Age $( \pm 1$ SD) & $45.8 \pm 0.5$ & $46.8 \pm 0.5$ \\
\hline
\end{tabular}

graphic age of the core interval. In addition, the biotite is euhedral and fresh, and we conclude that the calculated age is a reliable estimate of the crystallization age of the biotite.

\section{DISCUSSION}

Overall, there is a general trend in the characteristics of the clastic residues from the lower to the upper part of the middle Eocene section. The lowest interval studied (Sample 516F-78-3, 20-40 cm) contains pebbles of volcanic rock; subsequent intervals, up to Sample 516F$61-1,40-46 \mathrm{~cm}$, show first an abundance of lithic volcanic fragments and preservation of delicate features such as euhedral boundaries on biotite, then progressively more "mature" clastics showing increase in rounding and in alteration-resistant minerals such as quartz and feldspar. The general change from lower to higher intervals, from fine-grained lithic fragments to these coarser mineral fragments, also suggests a change in the nature of the source rocks, from volcanic to plutonic. However, much of the material at $516 \mathrm{~F}-72-1,84-85 \mathrm{~cm}$ may be plutonic.

The mixture of clay and coarse clastic fragments in the intervals studied could be explained in several ways. One possibility is that the sediment was deposited as an ash fall of mixed glass shards and lithic fragments. Subsequent alteration of glass to clay could have left the horizons of intermixed clay and sand. Alternatively, the dark clastic bands could represent poorly sorted turbidites derived from a weathered and eroded volcanic/plutonic terrain. Some of this material may be eroded and redeposited subaerial volcanic ash. Based on the geochronology of biotite separated from the Sample 516F76-4, 107-115 cm, volcanic ash eruptions occurred in the region in the middle Eocene. Possible sites of volcanism include hot-spot activity along the Martin Vas lineament to the north of the drilling site or further east along the Rio Grande Rise. Island arc volcanism associated with the Scotia Arc far to the south could also have generated explosive ash falls. A volcanic source along the Rio Grande Rise seems most probable, though further geochemical work on the biotite (and other volcanic fragments) may better characterize the source area.

The strikingly euhedral nature of the biotite (Plate 1, Fig. 4) seems to require a special history that, first, permits growth of euhedral crystals; second, permits transport of these delicate crystals to the site of deposition; and third, leaves them as free crystals suspended in a clay matrix containing other lithic and mineral fragments. The first requirement can be met by growth of the biotite as microphenocrysts in a quenched magma. The presence of this biotite as microphenocrysts in a highly vesiculated glassy volcanic ash would also meet the second and third requirements. Safe transport would be assured, whether by direct fallout from an ash cloud, or by erosion and transport of fresh ash as turbidity currents. This second mode of transport appears the most probable because of the graded bedding in many of the dark clastic horizons. Vesiculated glassy ash also meets the third requirement, because it would tend to weather rapidly and release the biotite.

Eocene volcanism producing such an ash is consistent with other evidence from the Rio Grande Rise. Fodor et al (1977) described alkalic trachybasalt and trachyandesite dredged from a locality west of Hole $516 \mathrm{~F}$. The high alkali and especially the high $\mathrm{K}_{2} \mathrm{O}$ content prompted them to compare these rocks with Tristan da Cunha, also known for its unusually potassic rocks. A highly potassic dacite that contains biotite would be a logical end-member of such a volcanic suite and probably would be associated with explosive ash eruptions. Nevertheless, Thompson and others (this volume) have shown that basement rocks at Hole $516 \mathrm{~F}$ are tholeitic, not alkalic, although they are more similar to "island tholeiites" than to typical mid-ocean ridge basalts. They suggest that volcanoes on the Rio Grande Rise may have evolved to more alkalic compositions with time, as has been observed in Hawaii and other oceanic volcanoes.

We conclude that erosion and redeposition of locally derived dacitic volcanic ash freshly erupted in the middle Eocene is most consistent with the age and petrographic characteristics of the biotite and clastic horizons. Associated fine-grained lithic fragments imply concurrent erosion of older volcanic terrain associated with this ash. Progressive erosion of this terrain is also suggested by the trend with time in successive clastic horizons, from a dominantly volcanic clastic assemblage to one dominated by more coarsely crystalline material suggestive of a plutonic source.

\section{ACKNOWLEDGMENTS}

D. Johnson provided the samples of the dark clastic horizons, and $\mathrm{S}$. Shor provided detailed descriptions of the sampled intervals as observed in the drill core. G. Thompson and S. Humphries provided additional helpful comments on the regional volcanic history that have contributed to the interpretation.

\section{REFERENCES}

Fodor, R. V., Husler, J. W., and Kumar, N., 1977. Petrology of volcanic rocks from an aseismic rise: implications for the origin of the Rio Grande Rise, South Atlantic Ocean. Earth Planet. Sci. Lett., 35:225-233.

Date of Initial Receipt: May 20, 1982

\section{APPENDIX}

\section{Descriptions of Core Intervals Studied}

Sample 516F-61-1, 40-46 cm. Greenish gray to pale olive (5Y6/3); relatively homogeneous, loosely consolidated, possibly expanded(?); clastic residue made up of coarse sand-sized dark fragments, fine- 
grained lithic fragments, rounded quartz grains, and angular feldspar fragments; a few large, irregularly shaped biotite flakes.

Sample 516F-61-3, 102-105 cm. Pale olive interval enclosing several relatively coarse bands and laminated pods; sharp upper and lower contacts against limestone; silt-sized clastic residue contains abundant dark, fine-grained lithic fragments; mineral fragments include biotite, quartz, feldspar, hypersthene, and chlorite.

Sample 516F-63-3, 8-40 cm. Olive to olive-gray $(5 Y 5 / 4,5 Y 5 / 2)$ interval, apparently two distinct turbidite units; coarse basal sandy interval $(18-28 \mathrm{~cm})$ in upper unit; minor burrowing near top of graded section; sandy interval with abundant lithic fragments and flakes of biotite enclosing acicular rutile.

Sample 516F-63-3, 121-125 cm. Bioturbated gray-green friable interval with no observable grading; fine sand-sized residue dominantly fine-grained, dark lithic fragments, and minor quartz, feldspar, and biotite.

Sample $516 \mathrm{~F}-63-4,27-33 \mathrm{~cm}$. Three olive-gray graded sandy layers $(30-33 \mathrm{~cm})$ overlain by gray clay $(27-30 \mathrm{~cm})$ with some bioturbation; similar to $516 \mathrm{~F}-63-3,121-125 \mathrm{~cm}$.

Sample 516F-66-2, 56-61 cm. Light gray (5Y7/2) friable interval, extensive bioturbation; clastic residue made up of fine to silt-sized sand and predominantly composed of fine-grained, "dirty" lithic frag- ments with minor feldspar, quartz, and possible amphibole; a few rare platy crystals of euhedral biotite.

Sample 516F-66-2, 137-142 cm. Similar to above, somewhat more friable with less bioturbation.

Sample 516F-72-1, 84-85 cm. Olive-gray sandy layer, consisting of silt to sand-sized, angular lithic fragments and feldspar; in some feldspar, polysynthetic twinning suggestive of anorthoclase or microcline; sand-sized fragments including feldspar, fine-grained dark lithic fragments, and a few coarse biotite fragments.

Sample 516F-75-5, 0-30 cm. Blue-gray matrix containing olivegray clasts, with no obvious grading; no sand-sized residue.

Sample 516F-75-5, 77-82 cm. Bluish gray sandy layers containing abundant opaque lithic fragments and scattered, irregularly shaped flakes of biotite.

Sample 516F-76-4, 90-140 cm. Olive-gray, relatively coarse micaceous sand comprising an interval of convoluted sandy beds; appears to be a definite turbidite unit; sand containing abundant cryptocrystalline lithic fragments (volcanic?) and flakes of subhedral to euhedral brown biotite.

Sample 516F-78-3, 20-40 cm. Dark greenish gray interval containing several rounded pebbles of volcanic rock (basalt); no sand-sized residue.
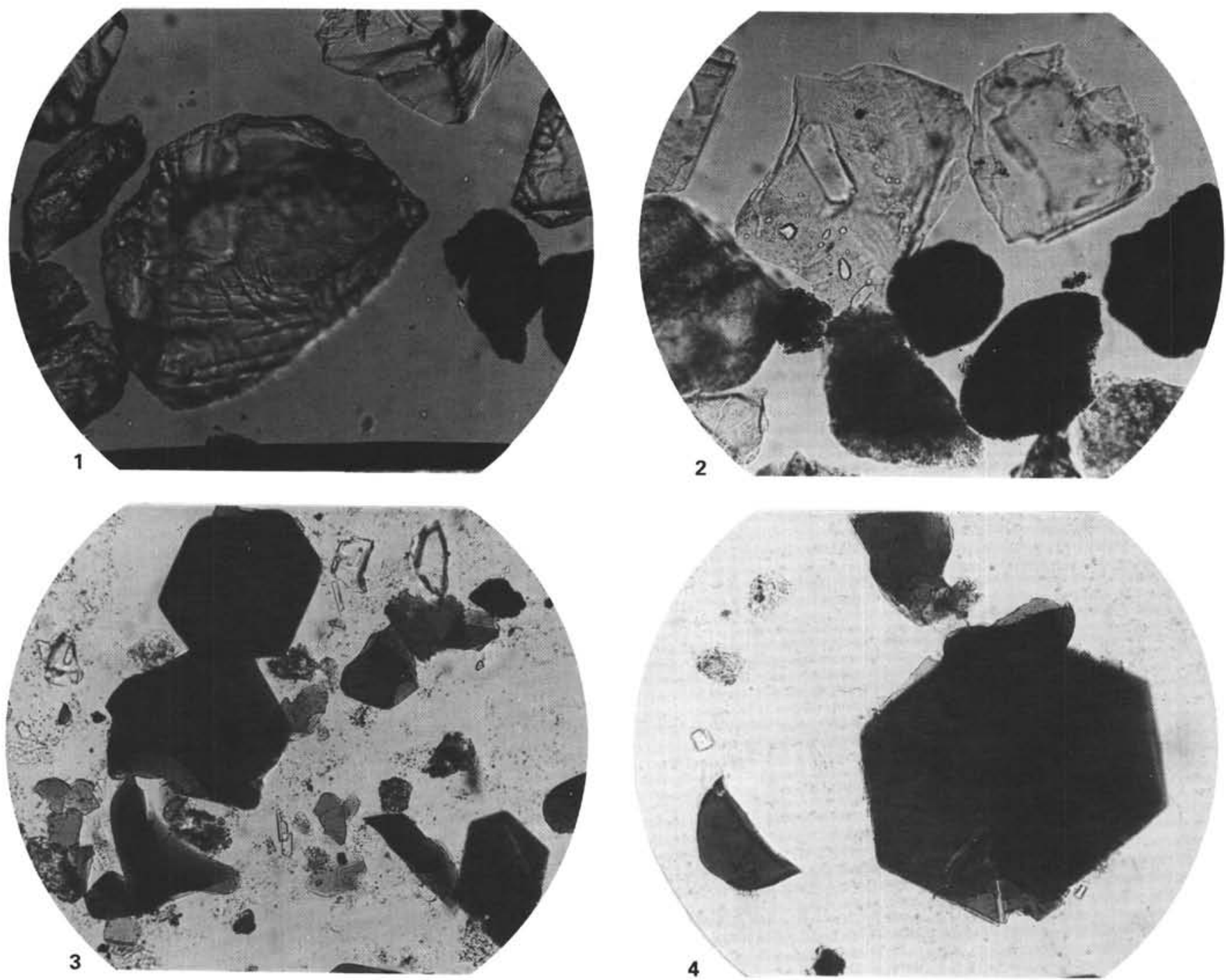

Plate 1. Width of field (the bottom line) in all photos is about $1 \mathrm{~mm}$. 1. Sample $516 \mathrm{~F}-61-1,44 \mathrm{~cm}$, rounded fragments of translucent quartz and feldspar in clastic residue. 2. Sample $516 \mathrm{~F}-72-1,84 \mathrm{~cm}$, angular fragments of feldspar, rounded opaque oxides, and a fine-grained, semiopaque lithic fragment in clastic residue. 3-4. Sample 516F-76-4, $125 \mathrm{~cm},(3)$ abundant euhedral and subhedral crystals and broken flakes of biotite dominate the clastic residue, accompanied by angular fragments of feldspar, (4) a detailed view of a large euhedral biotite crystal. 